\title{
Penerapan Tema Arsitektur Bioklimatik pada Perencanaan Beach Resort di Pantai Tanjung Papuma Jember
}

\author{
Agustian Edikusuma $^{1}$, Suci Ramadhani' ${ }^{2}$, Amir Mukmin Rachim ${ }^{3}$ \\ 1,2,3 Jurusan Arsitektur, Fakultas Teknik Sipil dan Perencanaan, Institut Teknologi Adhi Tama Surabaya \\ Email: 1 aedikusuma@gmail.com
}

\begin{abstract}
Abstrak. Jember is a district that has quite a lot of tourism and cultural opportunities that need to be introduced to local and foreign tourists. One of the tourist objects in Jember Regency, namely Tanjung Papuma Beach, is one of the interesting tourist objects to visit. This beach has beautiful white sand and hills with green trees, Papuma has pristine natural beauty. The potential of Tanjung Papuma beach, if properly managed and developed, can become one of the regional assets. It is important to provide supporting facilities. One of them is by providing accommodation with decent and comfortable facilities and equipped with karaoke and sports entertainment facilities, which can provide alternative entertainment for tourists. So as to create a comfortable atmosphere that can give an impression to visitors who come. The formation of a good tourism image in this Papuma beach tourist area, makes visitors come back again in the future to enjoy the tourism objects in that place. The method used in this research is design with qualitative amalisa, where analysis is carried out related to site conditions, climate, land use, general economic conditions, site vegetation conditions, facilities and infrastructure on the site, which then become a design concept and adjusted to the implementation. concept on working drawings. This research produces a design that aims to provide facilities for the coastal tourism of Tanjung Papuma with a bioclimatic architectural approach. The bioclimatic architectural approach aims to design buildings by paying attention to the environment, especially in the climate aspect. Which aims to save energy in buildings by taking advantage of the climate in the environment around the coast of Tanjung Papuma.
\end{abstract}

Keywords: bioclimatic architecture, beach, tourism

\begin{abstract}
Abstrak. Jember merupakan kabupaten yang memiliki cukup banyak peluang pariwisata dan kebudayaan yang perlu diperkenalkan kepada para wisatawan lokal maupun asing. Salah satu objek wisata yang ada di Kabupaten Jember yaitu Pantai Tanjung Papuma menjadi salah satu objek wisata yang menarik untuk dikunjungi. Pantai ini memiliki pasir putih yang indah dan bukit dengan pepohonan yang masih hijau, papuma memiliki keindahan alam yang masih asli. Potensi yang dimiliki pantai tanjung papuma ini jika dikelola dan dikembangkan dengan baik dapat menjadi salah satu aset daerah. Penyedia fasilitas pendukung pentingnya untuk dilakukan. Salah satunya, adalah dengan menyediakan tempat penginapan dengan fasilitas yang layak dan nyaman dan dilengkapi fasilitas hiburan karaoke dan olahraga, yang dapat memberikan hiburan alternatif bagi wisatawan. Sehingga tercipta suasana nyaman yang dapat memberikan kesan bagi pengunjung yang datang. Terbentukya citra wisata yang baik pada kawasan wisata pantai Papuma ini, membuat pengunjung kembali lagi di waktu mendatang untuk menikmati obyek wisata yang ada di tempat tersebut. Metode yang digunakan dalam riset ini adalah perancangan dengan amalisa kualitatif, dimana dilakukan analisa terkait dengan kondisi site, iklim, tata guna lahan, kondisi umum ekonomi, kondisi vegetasi tapak, sarana dan prasarana pada tapak, yang kemudian menjadi sebuah konsep desain dan disesuaikan dengan implementasi konsep pada gambar kerja. Penelitian ini menghasilkan perancangan yang bertujuan untuk menyediakan fasilitas pada wisata pantai tanjung papuma dengan pendekatan arsitektur bioklimatik. Pendekatan arsitektur bioklimatik bertujuan untuk mendesain bangunan dengan memperhatikan lingkungan terutama pada aspek iklim. Yang bertujuan menghemat energi pada bangunan dengan memanfaatkan iklim di lingkungan sekitar pantai tanjung papuma.
\end{abstract}

Kata kunci : Arsitektur bioklimatik, pantai, wisata

\section{Pendahuluan}

Jember merupakan kabupaten yang memiliki cukup banyak peluang pariwisata dan kebudayaan yang perlu diperkenalkan kepada para wisatawan asing maupun asing. Salah satu objek 
wisata yang ada di kabupaten Jember yaitu pantai tanjung papuma menjadi salah satu objek wisata yang menarik untuk dikunjungi. Pantai ini berada di selatan Kota Jember lebih tepatnya di Desa Lojejer, Kecamatan Wuluhan Kabupaten Jember Jawa Timur. Nama Papuma sendiri memiliki arti dari pasir putih dan malikan. Kata "Tanjung" ditambahkan di depannya, untuk menggambarkan posisi pantai yang menjorok ke laut arah barat daya dari wilayah itu. Selain pantainya, hutan yang terletak di sisi lainnya juga jadi daya tarik obyek wisata ini.

Banyak sekali keindahan yang disuguhkan di pantai ini. Hamparan pasir putih dengan tanjung melingkar dengan di kelilingi bukit yang terdapat banyak pepohonan hijau. Pantai Tanjung Papuma, dari 16 lokasi objek wisata terbaik yang telah dipromosikan oleh Perum Perhutani Unit II Jawa Timur pantai tanjung papuma merupakan salah satunya. Pantai ini memiliki keindahan alam yang masih asli.

Potensi yang dimiliki pantai tanjung papuma ini jika dikelola dan dikembangkan dengan baik dapat menjadi salah satu aset daerah. Penyedia fasilitas pendukung pentingnya untuk dilakukan. Salah satunya, adalah dengan menyediakan tempat penginapan dengan fasilitas yang layak dan nyaman dan dilengkapi fasilitas hiburan karaoke dan olahraga yang dapat memberikan hiburan alternatif bagi wisatawan. Sehingga tercipta suasana nyaman yang dapat memberikan kesan bagi pengunjung yang datang. Terbentukya citra wisata yang baik pada kawasan wisata pantai Papuma ini, membuat pengunjung kembali lagi di waktu mendatang untuk menikmati obyek wisata yang ada di tempat tersebut.

Melihat dari perkembangan teknologi pada bangunan yang sangat pesat, seakan kita lupa pentingnya akan keseimbangan dan keselarasan hubungan antara arsitektur dengan alam. Suatu konsep arsitektur yang mengangkat keselarasan, bentukan ide dari alam adalah arsitektur bioklimatik. Menurut Tumimomor et al. (2011) arsitektur Bioklimatik diterapkan pada bangunan yang sadar lingkungan dan hemat energi. Arsitektur Bioklimatik merupakan pendekatan untuk mendapatkan penyelesaian desain dengan memperhatikan hubungan antara arsitektur dengan lingkungan. Pengertian bioklimatik adalah Ilmu yang mempelajari antara hubungan iklim dan kehidupan terutama efek dari iklim pada kesehatan dan aktivitas sehari-hari. Konsep bioklimatik cocok diterapkan dalam sebuah perencanaan bangunan pendukung wisata. Karena, bentukan bangunan, struktur, maupun site plan bisa menyesuaikan dengan iklim dan lingkungan sekitar, karena tidak akan merusak alam sekitar site tersebut. Sehingga akan menciptakan suasana yang tenang dan asri.

Dari uraian tersebut di atas, maka di kawasan pantai Tanjung Papuma ini, di butuhkan sarana untuk menampung semua kegiatan yang mendukung pariwisata, yang bersifat fungsional, komersial dan rekreatif. Oleh karena itu, untuk mengatasi permasalahan tersebut, penting untuk dilakukan perencanaan dan perancangan beach resort di pantai tanjung papuma Jember dengan pendekatan arsitektur bioklimatik.

\section{Tinjauan Pustaka}

\subsection{Arsitektur Bioklimatik}

Arsitektur bioklimatik merupakan suatu pendekatan desain bangunan yang memperhatikan lingkungan sekitarnya terutama dalam hal iklim, dan bentuk arsitekturnya juga dapat dipengaruhi oleh budaya setempat. Pendekatan arsitektur bioklimtaik dapat mengurangi sumber - sumber energi yang tidak dapat diperbaharui (Tumimomor et al., 2011).

Ekologi menjadi dasar pertimbangan teori bioklimatik yang dikemukan oleh Yeang. Menurut Yeang merancang bangunan dengan pendekatan iklim akan mengurangi konsumsi energy pada bangunan dengan menggunakan struktur pasif (non-mekanik). Adapun prinsip-prinsip bioklimatik sebagai berikut.

a. Orientasi, Orientasi pada bangunan bioklimatik dioptimalkan pada sisi selatan dan utara yang memberikan keuntungan dalam penggunaan ventilasi itu sendiri. Untuk bangunan di daerah tropis, Yeang (1994) menyebutkan bahwa orientasi yang baik untuk bangunan adalah menghadap arah utara selatan.

b. Bukaan jendela, Untuk penempatan bukaan jendela sebaiknya menghadap arah selatan atau utara untuk menghindari radiasi cahaya matahari. Penggunaan shading juga menjadi suatu pemecahan untuk mengantisipasi radiasi matahari. 
c. Lansekap, Menurut Yeang (1994), Lansekap dan tumbuhan tidak hanya sebagai estetika saja tapi juga sebagai ekologi pada bangunan. Dengan adanya lansekap akan memberikan efek dingin pada bangunan karena dapat membantu pelepasan $\mathrm{CO} 2$ dan penyerapan $\mathrm{O} 2$.

d. Desain dinding, Desain dinding yang memiliki prinsip insulasi yang harus tetap dibuka pada saat musim kemarau. Desain dinding sebagai fungsi penyekat panas pada dinding, seperti pada struktur massa bangunan yang bekerja melepas panas saat siang hari. Solar heat atau solar window dapat diterapkan pada tampak gedung untuk menyerap panas matahari.

e. Transisi, Wujud dari area transisi bisa berupa atrium yang memiliki fungsi sebagai ruang udara. Angin akan diarahkan dari atrium ke ruang-ruang melaluli kisi-kisi atap bangunan.

f. Pembayangan pasif, Menurut Yeang (1994), pembayangan pasif berfungsi untuk membiaskan cahaya matahari pada bukaan atau dinding yang menghadap ke arah matahari langsung. Terdapat 2 sistem pembayangan pada desain dinding, pertama menampilkan 'taman di awan' yang membelit bangunan berbentuk spiral dengan penutup aluminium dan baja yang kedua membuat pembayangan dari plat aluminium di beberapa bidang bangunan untuk membayangi fasad bangunan.

g. Open plan, Denah bangunan sebaiknya ditentukan juga dengan fungsi bangunan yang akan ditampung, serta minim penyekatan. Dianjurkan adanya ventilasi atau bukaan alami (yang memungkinkan adanya sirkulasi silang) sebagai pengantar udara masuk ke dalam bangunan menuju ke luar bangunan. Selain itu dapat sebagai pergerakan udara dan cahaya yang melewati bangunan. (Amalia et al., 2014)

\subsection{Definisi Resort}

Resort merupakan tempat tinggal sementara bagi seseorang yang berada diluar tempat tinggalnya dengan tujuan untuk kesegaran jiwa dan raga. Resort juga disebut sebagai suatu usaha penginapan yang bertujuan untuk menginap keluarga ataupun perorangan selain bertujuan wisata di tempat yang berupa pondok-pondok rumah dan memiliki fasilitas pendukung berupa fasilitas penyegar, restoran dan laundry.

Menurut Gee (1988, dalam Utara, 2003) resort diartikan sebagai kawasan yang telah direncanakan sebagai penginapan selain itu bisa untuk rekreasi dan istirahat. Dari beberapa definisi tersebut dapat disimpulkan bahwa resort merupakan tempat penginapan yang memiliki fasilitas khusus, yang terletak pada lahan yang berada dikawasan objek wisata. Fasilitas khusus dapat berupa fasilitas olahraga, kesehatan, keagamaan serta keperluan usaha lainnya yang diakomodasi secara komersil.

Menurut (Pendit 1999) Resort merupakan sebuah tempat menginap dimana mempunyai fasilitas khusus untuk kegiatan bersantai dan berolah raga seperti tenis, golf, spa, tracking, dan jogging, bagian concierge berpengalaman dan mengetahui betul lingkungan resort, bila ada tamu yang mau hitch-hiking berkeliling sambil menikmati keindahan alam sekitar resor ini. Menurut A.S. Hornby (1974, dalam Utara, 2003) resort merupakan tempat wisata atau rekreasi yang sering dikunjungi orang dimana pengunjung datang untuk menikmati potensi alamnya, menambahkan terkait keterangan waktu dan tempatnya, menurut Echols (1987, dalam Utara, 2003) yaitu tempat peristirahatan di musim panas, di tepi pantai/di pegunungan yang banyak dikunjungi. Dari pengertian hotel dan resort di atas dapat disimpulkan bahwa Resort hotel adalah tempat penginanapan yang memiliki fasilitas rekreasi untuk para wisatawan yang berkunjung.

\section{Metode Penelitian}

Metode yang akan digunakan dalam perancangan yaitu metode kualitatif, merupakan metode riset yang sifatnya memberikan penjelasan dengan menggunakan analisis. Pelaksanaan dalam metode ini dengan proses penelitian yang fokus pada landasan teori. Adapun teknik pengumpulan data yang dipakai untuk mendukung dalam penelitian ini yaitu: Pengamatan, Dokumentasi, Metode Literatur, Studi banding. 


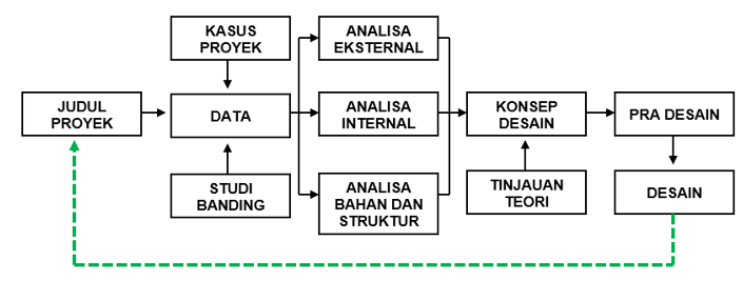

Gambar 1. Diagram Metode Penelitian.

Sumber: dokumen pribadi

\section{Analisa Lahan}

Tapak yang digunakan sebagai resort ini merupakan tapak yang berada pada pantai tanjung papuma Kabupaten Jember, Jawa Timur. Tapak ini memiliki luas $26.700 \mathrm{~m}^{2}$. Tapak memiliki batasbatas yaitu sebelah utara adalah parkiran existing pantai tanjung papuma, sebelah selatan adalah view pantai bagian selatan, sebelah barat merupakan hutan lindung pantai tanjung papuma. Untuk akses site dapat dijangkau menggunakan kendaraan pribadi dan kendaraan umum. Pada kendaraan pribadi bisa menggunakan mobil dan motor sedangkan untuk kendaraan umum maksimum ukuran kendaraannya adalah minibus.

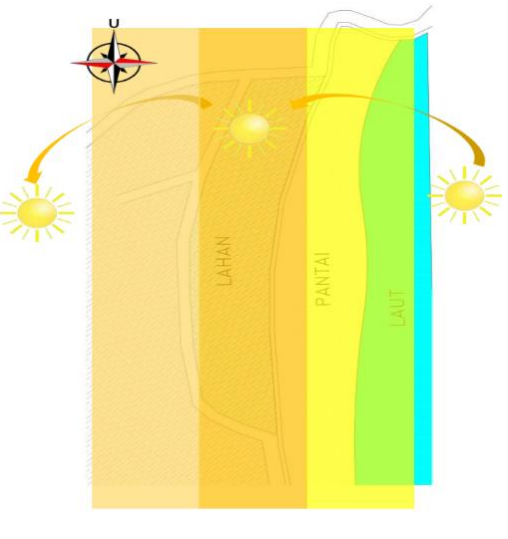

Analisa matahari

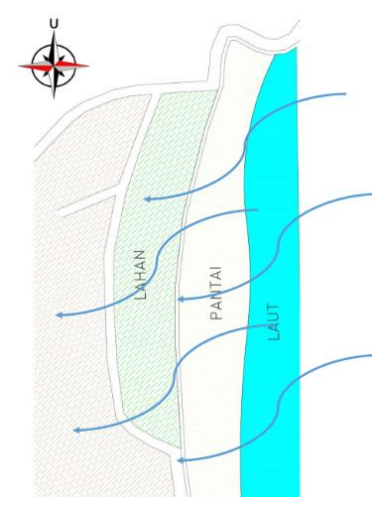

Analisa angin

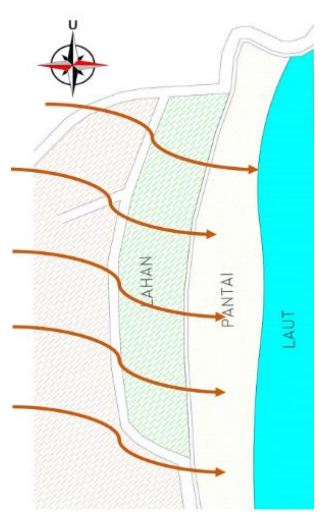

Analisa air hujan

Gambar 2. Analisa Tapak (matahari, angin, dan hujan)

Sumber: dokumen pribadi

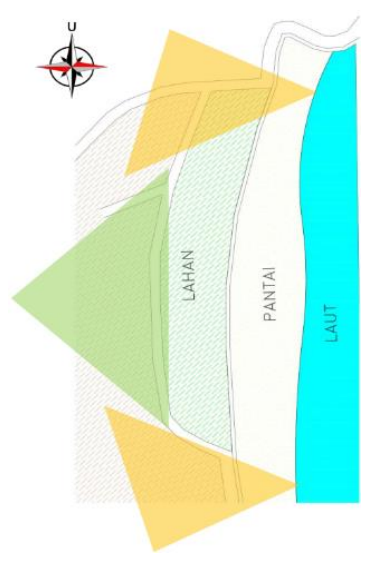

View to site

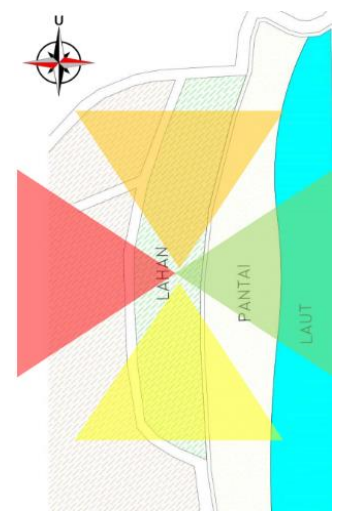

View from site

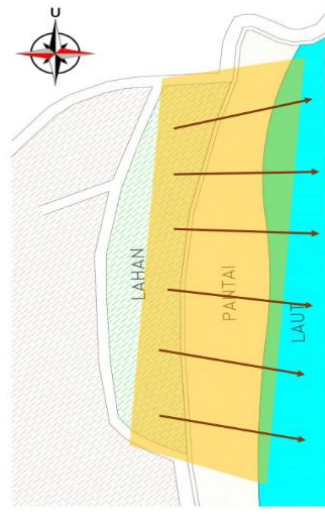

Orientasi

Gambar 3. Analisa Tapak (view from site, view to site, dan orientasi) Sumber: dokumen pribadi 
Dari sekian analisa tapak diatas ada beberapa analisa yang berpengaruh terhadap bentuk dan arah orientasi bangunan resort. Analisa matahari mempengaruhi finishing fasad bangunan yang akan menerapkan sun shading, pada analisa angin akan berkaitan dengan sirkulasi udara pada bangunan, sedangkan analisa air hujan berkaitan dengan atap bangunan yang akan ditentukan. Analisa-analisa diatas ini dapat membantu dalam menerapkan tema arsitektur bioklimatik, yang di mana arsitektur ini berkaitan dengan iklim sekitar.

\section{Pembahasan}

Untuk tatanan lahan konsep adalah "Adaptif”. Prinsip-prinsip desain arsitektur bioklimatik yaitu dengan (a) memperhatikan keuntungan matahari (b) meminimalkan perlakuan aliran panas (c) meminimalkan bukaan terhadap matahari (d) memperhatikan ventilasi. Penerapan konsep "Adaptif" ini berdasarkan prinsip-prinsip desain pada arsitektur bioklimatik, sehingga desain dapat menyesuaikan dengan iklim yang ada disekitar.

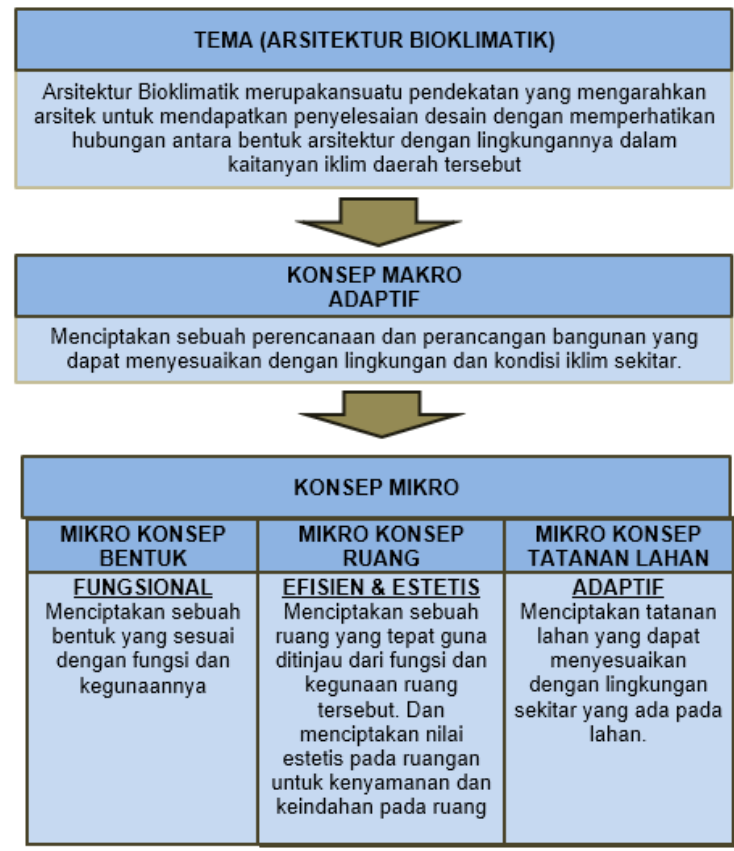

Gambar 4. Diagram Konsep Rancangan Sumber: dokumen pribadi

Dalam menerapkan konsep ini harus memperhatikan berbagai analisa lahan terhadap iklim seperti analisa matahari, analisa angin, analisa air hujan, dan analisa suhu. Penerapan konsep ini bertujuan sebagai berikut (a) mengoptimalkan pencahayaan bangunan dengan memanfaatkan cahaya matahari (b) memanfaatkan arah angin sebagai sirkulasi udara pada bangunan .

Dalam penerapan arsitektur bioklimatik transformasi lahan didesain berdasarkan analisa iklim dan arah angin pada lokasi pantai tanjung papuma untuk mendapatkan dan orientasi lahan yang adaptif. Transformasi lahan dirancang untuk dapat memanfaatkan sinar matahari dan angin yang ada pada lokasi.

Konsep perancangan bentuk pada bangunan adalah "Fungsional". Menurut Yeang Kenneth prinsip-prinsip desain arsitektur bioklimatik secara ekologi adalah: (a) Penggunaan balkon pada bangunan dapat memberikan keteduhan pada sisi panas bangunan; (b) Dinding, pada daerah tropis dinding luar harus bias digerakkan yang mengendalikan dan cross ventilation untuk kenyamanan dalam bangunan; (c) Menggunakan alat pembayangan pasif yang berfungsi untuk membiaskan cahaya matahari pada dinding yang menghadap ke arah matahari langsung; (d) Bukaan jendela, bukaan jendela sebaiknya menghadap arah utara dan selatan untuk mendapatkan orientasi pandangan (Mesiniaga et al., 2011). Konsep "Fungsional" dalam bentuk bangunan ini yaitu sebagaimana bentuk 
bangunan memiliki fungsi yang baik dalam menyesuaikan iklim yang ada disekitarnya dengan memperhatikan prinsip desain arsitektur bioklimatik secara ekologi. Penerapan dalam konsep ini antara lain: (a) memanfaatkan dan mengoptimalkan pencahayaan dan penghawaan alami; (b) menyesuaikan orientasi bangunan dengan penataan lahan yang ada pada tapak; dan (c) menerapkan sun shading pada fasad bangunan untuk mengurangi cahaya matahari yang berlebihan

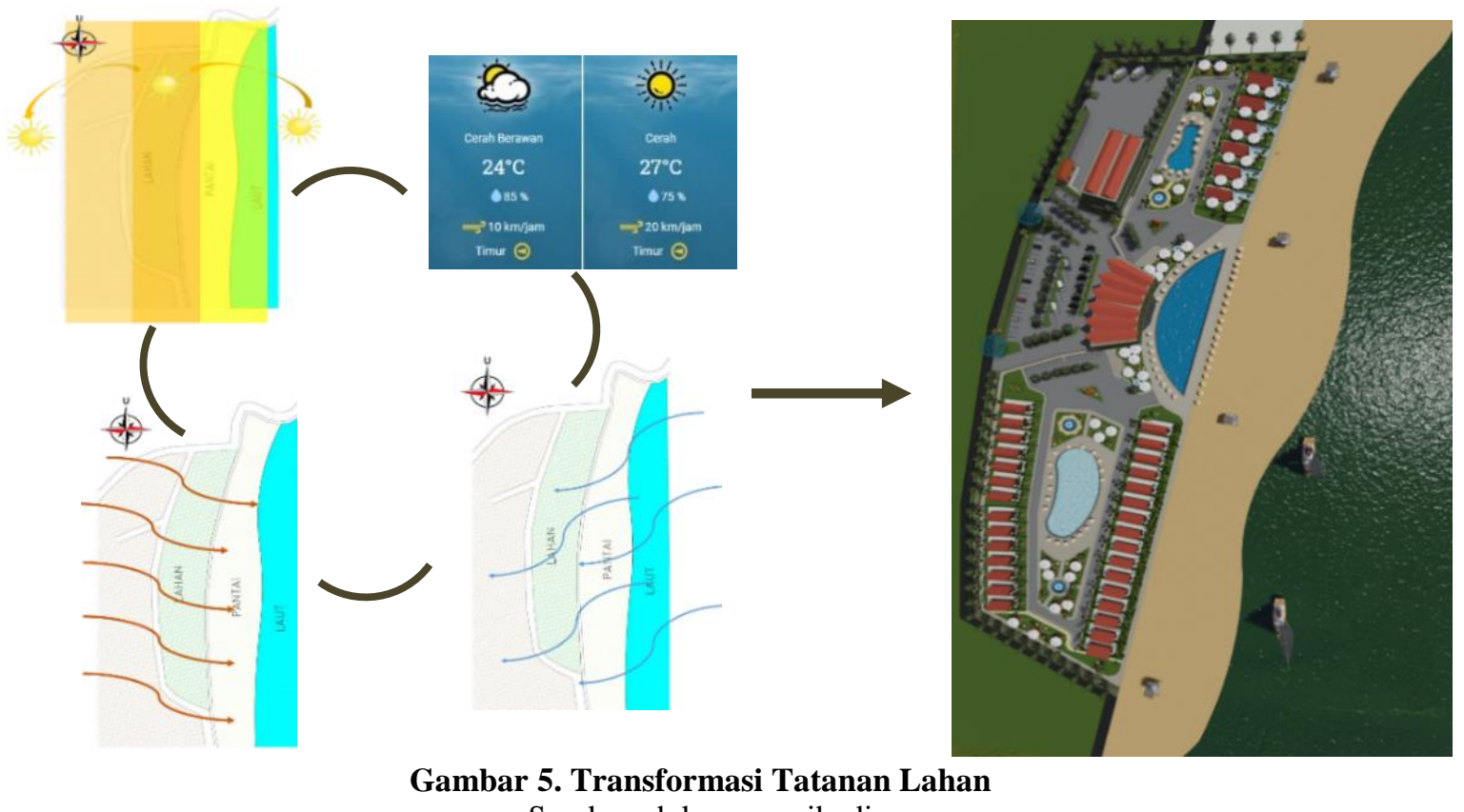

Sumber: dokumen pribadi

Penerapan arsitektur bioklimatik pada bangunan ini didasarkan dari teori bioklimatik yang dikemukan oleh Yeang, penerapan ini untuk mengurangi dampak dari sinar matahri dan angin yang berlebihan dari arah pantai (lihat Gambar 5).

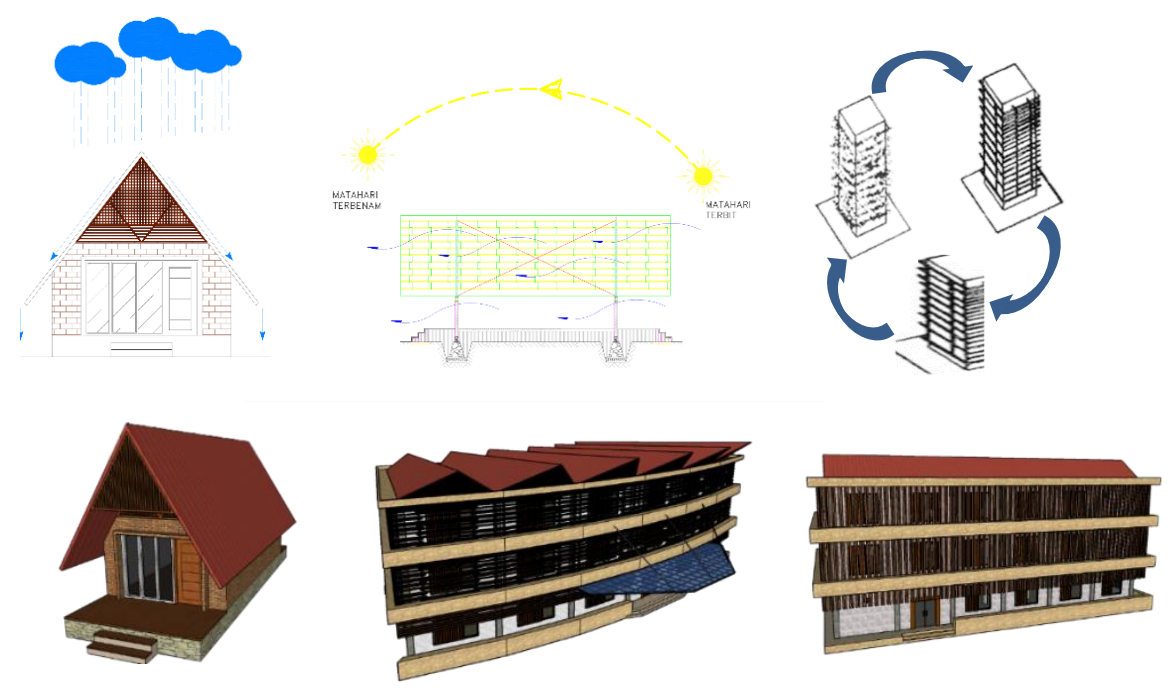

Gambar 6. Transformasi Bentuk Bangunan.

Sumber: dokumen pribadi

Pada transformasi bentuk resort menyesuaikan dengan iklim yang ada pada lokasi. Indonesia merupakan negara yang memiliki iklim tropis sehingga bentuk bangunan yang memiliki atap pelana 
sangat cocok pada iklim tropis. Penggunaan sun shading pada bangunan sangat penting untuk mengantisipasi sinar matahari yang berlebihan.
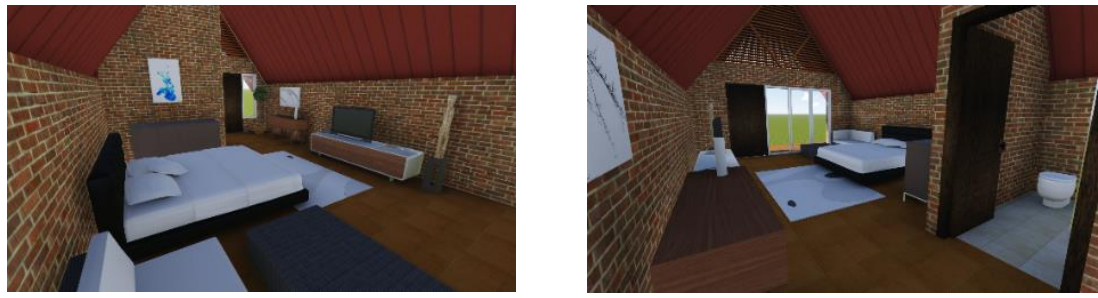

Gambar 7. Transformasi Bentuk Bangunan.

Sumber: dokumen pribadi

Konsep perancangan ruang adalah "Efisien \& Estetis". Prinsip perancangan resort yang dapat merespon dengan alam yaitu: (a) memasukan elemen alam ke dalam bangunan; (b) keterbukaan pada ruang berfungsi sebagai kontak antara ruang dengan alam; (c) peletakan bukaan ruang yang tepat pada keindaan alam; dan (d) menempatkan bukaan yang lebar yang mengadap langsung ke alam (Martina Amboro Mawardi, 2015). Penerapaan konsep "Efisien \& Estetis" pada ruang untuk dapat memenuhi prinsip dari perancangan resort yang dapat merespon alam yang bertujuan untuk menciptakan sebuah ruangan yang tepat guna dan dapat menyesuaikan dengan iklim yang ada dilingkungan site, serta keindahan pada ruang dapat memberikan kenyamanan pengguna.

\section{Kesimpulan}

Resort ini di desain sebagai fasilitas pendukung pariwisata pantai yang bisa menjadikan salah satu aset daerah. Salah satunya memberikan hiburan alternatif bagi wisatawan. Sehingga tercipta suasana nyaman yang dapat memberikan kesan bagi pengunjung yang datang. Terbentukya citra wisata yang baik pada kawasan wisata pantai kelapa ini, membuat pengunjung kembali lagi di waktu mendatang untuk menikmati obyek wisata yang ada di tempat tersebut.

Tema dalam Perencanaan dan Perancangan ini adalah arsitektur arsitektur bioklimatik merupakan suatu pendekatan desain bangunan yang memperhatikan lingkungan sekitarnya terutama dalam hal iklim. Arsitektur bioklimatik dalam penerapannya memiliki kemampuan menghemat penggunaan energi sehingga mempunyai konsumsi biaya yang rendah dalam operasionalnya. Masalah Ekologi desain dengan iklim menggunakan perangkat non mekanik sehingga ramah lingkungan. Dalam penerapan arsitektur bioklimatik pada perancangan adalah sebagai berikut: (a) Tatanan lahan dibuat adaptif mengikuti arah matahari dan arah angin untuk memaksimalkan sinar matahari di siang hari guna menghemat energi di siang hari; (b) Pada bentuk bangunan di beri pembayangan pasif untuk mengurangi masuknya sinar matahari berlebihan. Penggunaan atap pelana pada bangunan untuk menghadapi curah hujan yang tinggi; dan (c) Konsep ruang yang digunakan efisien dan estetis yang dimana besaran ruang sudah diperhitungkan berdasarkan keadaaan iklim sekitar dan memberikan kesan estetis pada ruang untuk kenyamanan pengunjung

\section{Referensi}

Amalia, N., Nugroho, A. M., \& Asikin, D. (2014). Fasad Bioklimatik pada Rancangan Perpustakaan Umum di Kedung Kandang Kota Malang. Jurnal Mahasiswa Jurusan Arsitektur Universitas Brawijaya, 2(2).

Martina Amboro Mawardi. (2015). Jung Para Resort Hotel Dengan Fasilitas Ekowisata Mangrove Di. https://lib.unnes.ac.id/21838/1/5112410010-S.pdf

Mesiniaga, M., Selangor, D. I., Budaya, M., Kuala, D. I., Menara, D. A. N., \& Di, U. (2011). Terhadap Kenyamanan Termal Pada Bangunan Tinggi Karya Ken Yeang : September.

Tumimomor, I. A. G., Poli, H., Prodi, M., Unsrat, A., Pengajar, S., Arsitektur, P., Lingkungan, R., Alami, D. A., \& Umum, D. (2011). Arsitektur Bioklimatik. Media Matrasain, 8(1).

Utara, U. S. (2003). Universitas Sumatera Utara 4. 4-16. 
